Gaston, E. A. (1948). New Engl. F. Med. 238, 345.

Gracey, M., Burke, V. \& Oshin, A. (1970). Lancet ii, 827 .

Gray, G. M. (1970). Gastroenterology 58, 96.

Gray, G. M. \& Ingelfinger, F. J. (1966). \%. clin. Invest. 45, 388 .

Gray, G. M. \& Santiago, N. A. (I966). Gastraenterology 5I, 489 .

Gray, G. M. \& Santiago, N. A. (Ig6g). \%. clin. Invest. 48, 7I6.

Gray, G. M., Santiago, N. A., Colver, E. H. \& Genel, M. (r 969$)$. F. clin. Invest. 48, 729.

Greaves, J. P. \& Hollingsworth, D. F. (1964). Proc. Nutr. Soc. 23, 136.

Holdsworth, C. D. \& Dawson, A. M. (I964). Clin. Sci. 27, 37 r.

Holdsworth, C. D. \& Dawson, A. M. (1965a). Proc. Soc. exp. Biol. Med. r18, 142.

Holdsworth, C. D. \& Dawson, A. M. $(1965 b)$. Gut 6, 387.

McMichael, H. B. \& Dahlqvist, A. (1968). Gut 9, 365 .

McMichael, H. B., Webb, J. \& Dawson, A. M. (1966). Br. med. F. ii, I037.

McMichael, H. B., Webb, J. \& Dawson, A. M. (r967). Clin. Sci. 33, г35.

Meeuwisse, G. \& Melin, K. (1969). Acta paediat., scand. suppl. 188, 3 .

Neale, G. (I 968 ). Hosp. Med. 2, 1372.

Newcomber, A. D. \& McGill, D. B. (r966). Gastroenterology 5r, $48 \mathrm{r}$.

Olsen, W. A. \& Ingelfinger, F. J. (1968). F. clin. Invest. 47, I 133 .

Rider, A. K., Schedl, H. P., Nokes, G. \& Shining, S. (1967). \%. gen. Physiol. 50, 1173.

Rosenweig, N. S. (I97I). Gastroenterology 60, 464 .

Schedl, H. P. \& Clifton, J. A. (1961). F. clin. Invest. 40, 1079.

Schmerling, D. H., Auricchio, S., Rubino, A., Hadorn, B. \& Prader, A. (1964). Helv. paediat. Acta I9, 507 .

Ugolev, A. M. (1965). Physiol. Rev. 45, 555.

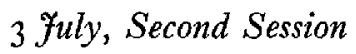

\section{Chairman : Professor A. T. Phillipson, MA, PhD, DVSc, MRCVS, School of Veterinary Medicine, University of Cambridge}

\section{Carbohydrate metabolism in the domestic fowl}

By J. Pearce, Department of Agricultural Chemistry, Queen's University of Belfast, Belfast BT, $6 B B$ and Ministry of Agriculture, Northern Ireland

In contrast to the situation in the mammal, particularly the rat for which there is a large volume of literature on carbohydrate metabolism, it is only in recent years that any concentrated effort has been made on this aspect of metabolism in the domestic fowl. This paper will review the present state of knowledge on intracellular carbohydrate metabolism during the development of the chicken and some interrelationships with lipid metabolism will also be discussed.

\section{Gluconeogenesis and glycogen metabolism in the embryonic and neonatal chick}

Glucose is necessary for the development of the chick embryo and since the hen's egg contains only traces of carbohydrate it is not unexpected that gluconeogenesis is active in the embryo (Kilsheimer, Weber \& Ashmore, I960; Ballard \& Oliver, I963). During incubation the gluconeogenic enzymes, pyruvate carboxylase (EC 6.4.r.r.), phosphopyruvate carboxylase ( $E C$ 4.I.I.32), hexosediphosphatase ( $E C$ 3.I.3.II) and glucose-6-phosphatase $(E C$ 3.x.3.9), increase in activity to maxima on the 
r6th and 17 th days of incubation and then decrease towards hatching (Rinaudo, 196r; Nelson, Yarnell \& Wagle, 1966; Felicioli, Gabrielli \& Rossi, I967). Glycogen first appears in chick embryonic liver on the 6th day of incubation (Dalton, I937) and increases to a maximum concentration on the I 9 th day of incubation (Gill, 1938 ; Ballard \& Oliver, 1963 ). During this time there is a parallel increase in the activities of the enzymes of glycogen metabolism (Ballard \& Oliver, 1963).

At the end of the incubation period, hepatic glycogen is rapidly metabolized (Muglia \& Massuelli, 1934; Gill, 1938) and falls from $19.0 \mathrm{mg} / \mathrm{g}$ liver in the $18 \cdot 5$ d-old embryo to $\mathrm{r} \cdot 6 \mathrm{mg} / \mathrm{g}$ liver $\mathrm{I}$ d after hatching with a concomitant increase in blood sugar (Freeman, 1965). Glycogen probably serves as an energy source for hatching.

On hatching there is a change in diet from that of the embryo which has a highfat content with only traces of carbohydrate to a relatively high-carbohydrate diet. Consequently, the gluconeogenic and glycogenic pathways which are present in high activity in the embryo decrease on hatching. Hepatic hexosediphosphatase and glucose-6-phosphatase activities decrease after hatching, and lower activities are observed in adult fowl than in late embryonic or newly hatched birds (Rinaudo, 196r; Nelson et al. r966; Wallace \& Newsholme, r967).

In contrast, gluconeogenesis and glycogenesis in the mammalian foetus are very limited (Ballard \& Oliver, I963, I965; Nelson et al. r 966; Yarnell, Nelson \& Wagle, 1966). This is probably because the foetus is provided with a constant glucose supply from the maternal blood. At birth the mammal is presented with a high-fat, low-carbohydrate diet (milk) and during this neonatal period glucose is formed by gluconeogenesis (Ballard \& Oliver, I965; Nelson et al. 1966; Yarnell et al. 1966; Yeung, Stanley \& Oliver, ${ }^{967}$ ). Glycogenesis also increases in the neonatal mammal and reaches maximum levels shortly after birth (Ballard \& Oliver, 1963, 1965).

\section{Glycolysis and the pentosephosphate pathway in the embryonic and neonatal chick}

The presence of glycolysis in the chick embryo was first clearly demonstrated by Meyerhof \& Perdigon (1940).

The rate of glycolysis in chick embryonic muscle tissue (Arese, Rinaudo \& Bosia, 1967) and the activities of glycolytic enzymes in the liver (Rinaudo, 1962; Wallace \& Newsholme, 1967 ) increase during incubation so that the capacity to utilize carbohydrate is available after hatching when the animal receives a carbohydraterich diet. Phosphofructokinase ( $E C$ 2.7.I.II) and pyruvate kinase ( $E C$ 2.7.I.40) increase in activity in the liver until at least $8 \mathrm{~d}$ after hatching; much lower activities are found in adult birds (Wallace \& Newsholme, 1967). Glucosephosphate isomerase ( $E C$ 5.3.I.9), glyceraldehydephosphate dehydrogenase $(E C$ I.2.1.12) and phosphopyruvate hydratase ( $E C$ 4.2.I.II) are lower in activity at 3 months than in newly hatched chicks (Rinaudo, I 962 ), and Goodridge (1968b) reported that hepatic glyceraldehydephosphate dehydrogenase and glycerolphosphate dehydrogenase (EC r.I.99.5) decrease in activity between 2 and 4 weeks after hatching.

Hexokinase (EC 2.7.I.I) activity is very low in embryonic liver and there is no detectable glucokinase ( $E C$ 2.7.r.2) activity; hexokinase activity increases $4 \mathrm{~d}$ after 
hatching and is higher in the adult bird than in the newly hatched chick whereas for all other glycolytic enzymes investigated the converse applies (Wallace \& Newsholme, 1967). Glucokinase activity in adult birds is only $25 \%$ that of hexokinase (Wallace \& Newsholme, 1967) whereas in the rat, glucokinase activity is about three times that of hexokinase (Viñuela, Salas \& Sols, 1963 ).

The activity of the pentosephosphate pathway has been investigated in chick embryonic tissues (Liuzzi \& Angeletti, 1964; Coffey, Cheldelin \& Newburgh, 1964) by determining the evolution of $\left[{ }^{14} \mathrm{C}\right]$ carbon dioxide from $\left[{ }^{[-1}-{ }^{14} \mathrm{C}\right]$ glucose and $\left[6-{ }^{14} \mathrm{C}\right]$ glucose by the method described by Bloom, Stetten \& Stetten (1953). The activity of glucose-6-phosphate dehydrogenase ( $E C$ r.I.I.49) and the metabolism of ribose-5-phosphate by extracts of brain, liver or whole embryo mirror the total activity of the pentosephosphate pathway (Cazorla \& Guzman Barron, 1958; Burt $\&$ Wenger, 1961 ), and generally the peak of activity is found between the 4 th and 8th day of incubation. This pathway then declines in activity with increasing time of incubation until at hatching it is virtually non-existent. In the chick embryo this pathway is probably important in providing pentoses for nucleic acid biosynthesis and reduced NADP for reductive syntheses involved in differentiation.

Very little information is available on the activity of the pentosephosphate pathway after hatching. The pentosephosphate pathway dehydrogenases in the liver and adipose tissue change very little in activity between the roth day of incubation and $26 \mathrm{~d}$ after hatching (Goodridge, 1968b). Indirect information on the activity of the pentosephosphate pathway from respiratory studies has shown that glycolysis is the predominant pathway of glucose catabolism in the hatched chick with the pentosephosphate pathway playing only a minor role (Duncan $\&$ Common, 1967; Duncan, 1968).

\section{Carbohydrate metabolism in relation to lipogenesis}

Most of the work carried out on carbohydrate metabolism in the chicken after hatching has been in relation to lipogenesis. Lipogenesis in mammals is active in foetal liver, but after birth decreases rapidly presumably because of the high-fat content of the milk on which the young are fed (Taylor, Bailey \& Bartley, 1967); after the suckling period, lipogenesis from carbohydrate sources again increases. In the domestic fowl the reverse situation occurs and lipogenesis in the chick embryo is very low (Kilsheimer et al. 1960). This pathway in the chick liver, measured by the incorporation of glucose into fatty acids, increases rapidly on hatching and feeding to a maximum $7-8 \mathrm{~d}$ after hatching when the rate is about 1000 times that in embryonic liver (Goodridge, 1968a). In the domestic fowl, the liver is the main site of lipogenesis (Goodridge, 1968c; O'Hea \& Leveille, 1969a) whereas the adipose tissue is the major site in the mouse, rat and pig (Favarger, 1965; Leveille, 1967; O'Hea \& Leveille, $\mathrm{I} 969 b)$.

The activities of several liver and adipose tissue enzymes which are involved in glucose metabolism, and the conversion of glucose to lipids were examined by Goodridge ( $1968 b)$. In the non-ruminant, citrate, derived from glucose, is the main carbon source for lipogenesis and is converted to acetyl-CoA by ATP citrate 
lyase (EC 4.1.3.8). The malate dehydrogenase (decarboxylating) (NADP) (EC I.I.I.40) is also involved in this 'citrate-cleavage pathway' and is a source of reduced NADP which can be used in fatty acid biosynthesis. Goodridge (1968b) found that the activities of these enzymes are low in embryonic liver but increase rapidly on hatching and feeding to reach maximum activities at I week old, whereas in the adipose tissue their activities remain low from the late embryonic stage until at least 4 weeks after hatching.

The pentosephosphate pathway is implicated in lipogenesis in mammals as a source of reduced NADP (Masoro, 1962) but, in the chicken, enzyme studies suggest that this pathway plays only a minor role in hepatic lipogenesis (Goodridge, $1968 b)$.

The hepatic activities of ATP citrate lyase and malate dehydrogenase (decarboxylating) (NADP) increase in the pullet with the onset of sexual maturity whereas in the cockerel there are no differences in the activities of these enzymes between mature and immature birds (Pearce, 1971 $a$ ). In these studies several glycolytic enzymes were also investigated. These showed no variation in activity with the onset of sexual maturity, suggesting that the increased lipogenesis in the laying hen is due to a specific stimulation of lipogenesis and not a general increase in metabolism.

\section{Carbohydrate metabolism in the mature and immature domestic fowl}

The onset of sexual maturity in the female domestic fowl is accompanied by increases in various liver and plasma constituents in relation to egg production. This might be presumed to involve an increased activity of the pentosephosphate pathway to provide the reduced NADP required for these synthetic processes.

Duncan \& Common ( 1967 ) investigated the pentosephosphate pathway and concluded that it is not operative to any great extent in the liver of the immature and mature domestic fowl. Also there is no increase in hepatic pentosephosphate pathway activity in the pullet during the onset of sexual maturity (I $5^{-2 I}$ weeks of age). The in vivo or in vitro addition of oestradiol to immature pullets similarly has no effect on hepatic glucose metabolism; the in vivo administration of oestrogen increases pentosephosphate pathway activity in rat liver (McKerns \& Bell, 1960). The incorporation of radioactivity from $\left[{ }^{1}-{ }^{14} \mathrm{C}\right]$ glucose and $\left[{ }^{6-14} \mathrm{C}\right]$ glucose into $\mathrm{CO}_{2}$, total lipid, fatty acids and glyceride-glycerol also shows that glycolysis is the major route of hepatic glucose metabolism (Duncan, r968) and no changes in the incorporation of glucose into these components are observed with the onset of sexual maturity. Similarly, Pearce (1971 $a$ ) found that there is no increase in the activities of the hepatic glycolytic enzymes, phosphofructokinase, fructosediphosphate aldolase ( $E C$ 4.1.2.13) and pyruvate kinase, with the commencement of egg laying.

\section{Effect of diet on the pathways of carbohydrate metabolism}

The effects of dietary modification on the interrelation of carbohydrate metabolism and lipogenesis in mammals is well known. Only in recent years have similar studies been carried out in the domestic fowl. 
Kidney slices from chickens given a low-carbohydrate, high-lipid diet (boiled eggs) show a high rate of gluconeogenesis (Krebs \& Yoshida, 1963). This is accompanied by an increase in the activities of the gluconeogenic enzymes (Rinaudo \& Galletti, I966). Similarly, the hepatic activities of gluconeogenic enzymes increase whereas those involved in glycolysis decrease when 'carbohydrate-free' (high-lipid) diets are given to the neonatal chick (Allred \& Roehrig, 1970).

The inclusion of lipid in the diet of mature and immature domestic fowl also results in a reduced rate of lipogenesis from carbohydrate sources (Pearce, I968; Balnave \& Pearce, 1969; Yeh, Leveille \& Wiley, I970; Pearce, I971b).

The metabolism of fructose by the chick is of interest because it is virtually absent from the tissues but is rapidly absorbed from the intestine. Heald $\left(196_{3}\right)$ and Hawkins \& Heald ( 1966 ) noted that the metabolism of fructose and of glucose by avian liver slices is quantitatively different. Fructose stimulates the respiration of liver slices more than glucose and also increases lipogenesis. This phenomenon of increased lipogenesis from fructose or sucrose is well known in mammals. The relative rates of lipogenesis from fructose and glucose have been investigated at the enzyme level and no significant differences are found in the specific activities of the lipogenic enzymes, ATP citrate lyase, the malate dehydrogenase (decarboxylating) (NADP) and acetyl-CoA carboxylase (EC 6.4.1.2), or the glycolytic enzymes, pyruvate kinase and lactate dehydrogenase ( $E C$ I.I.1.27) with diet, indicating that these enzymes are not rate-limiting in lipogenesis (Pearce, 1970). Ketohexokinase (EC 2.7.1.3) activity is increased on fructose feeding and has a much higher activity than either hexokinase or glucokinase which suggests that fructose is predominantly metabolized as fructose-I-phosphate. The presence of ketose-I-phosphate aldolase ( $E C$ 4.I.2.7) in chick liver, capable of metabolizing fructose-I-phosphate, shows that it does not differ qualitatively from mammalian liver. The increased rates of respiration and lipogenesis from fructose as compared with glucose may reflect the relative ease with which fructose can be converted to acetyl-CoA by chicken liver; the metabolism of fructose via fructose-I-phosphate would account for these differences.

It is noteworthy that the specific activity of hepatic pyruvate kinase is not affected by dietary modification. Various dietary levels of fructose and fat-feeding have no effect on hepatic pyruvate kinase in the chicken (Pearce, 197Ic) whereas, in the rat, fructose induces pyruvate kinase activity (Bailey, Taylor \& Bartley, I968; Szepesi \& Freedland, I968) and dietary lipid represses it (Taylor et al. 1967). These results suggest that chicken liver is more restricted in its response to dietary modification than rat liver.

In conclusion, the information presently at hand shows that the pathways of carbohydrate metabolism in the domestic fowl and mammalian species are qualitatively similar but there are quantitative differences. These differences can largely be explained by the different development and associated diet of avian species. 
Bailey, E., Taylor, C. B. \& Bartley, W. (1968). Nature, Lond. 217, 471.

Ballard, F. J. \& Oliver, I. T. (1963). Biochim. biophys. Acta 71, 578.

Ballard, F. J. \& Oliver, I. T. (I965). Biochem. F. 95, 19r.

Balnave, D. \& Pearce, J. (1969). Comp. Biochem. Physiol. 29, 539.

Bloom, B., Stetten, M. R. \& Stetten, D. Jr (r953). F. biol. Chem. 204, 681.

Burt, A. M. \& Wenger, B. S. (1961). Devel. Biol. 3, 84 .

Cazorla, A. \& Guzman Barron, E. S. (1958). Expl Cell Res. 14, 68.

Coffey, R. G., Cheldelin, V. H. \& Newburgh, R. W. (1964). F. gen. Physiol. 48, ro5.

Dalton, A. J. (1937). Anat. Rec. 68, 393.

Duncan, H. J. (1968). Can. F. Biochem. 46, 1321.

Duncan, H. J. \& Common, R. H. (1967). Can. F. Biochem. 45, 979.

Favarger, P. (1965). In Handbook of Physiology, Adipose Tissue Sect. 5, Ch. 4, p. 19 [A. E. Renold and G. F. Cahill, Jr, editors]. Washington, D.C.: American Physiological Society.

Felicioli, R. A., Gabrielli, F. \& Rossi, C. A. (1967). Eur. F. Biochem. 3, 19.

Freeman, B. M. (1965). Comp. Biochem. Physiol. x4, 217.

Gill, P. M. (1938). Biochem. F. 32, 1792.

Goodridge, A. G. (1 968a). Biochem. $\mathscr{F} .108,655$.

Goodridge, A. G. (1968b). Biochem. F. xо8, 663.

Goodridge, A. G. (1968c). Am. F. Physiol, 214, 897 .

Hawkins, R. A. \& Heald, P. J. (1966). Biochim. biophys. Acta 116, 4I.

Heald, P. J. (1963). Biochem. F. 86, то3.

Kilsheimer, G. S., Weber, D. R. \& Ashmore, J. (I960). Proc. Soc. exp. Biol. Med. ro4, 515.

Krebs, H. A. \& Yoshida, T. (I963). Biochem. F. 89, 398.

Leveille, G. A. (1967). Proc. Soc. exp. Biol. Med. 125, 85.

Liuzzi, A. \& Angeletti, P. U. (1964). Experientia 20, 5 I2.

McKerns, K. W. \& Bell, P. H. (1960). Recent Prog. Horm. Res, 16, 97.

Masoro, E. J. (1962). F. Lipid Res. 3, 149.

Meyerhof, O. \& Perdigon, E. (1940). Enzymologia 8, 353.

Muglia, G. \& Massuelli, L. (1934). Boll. Soc. ital. Biol. sper. 8, 1772.

Nelson, P., Yarnell, G. \& Wagle, S. R. (1966). Archs Biochem. Biophys. 1 4, 543.

O'Hea, E. K. \& Leveille, G. A. (I969a). Comp. Biochem. Physiol. 30, 149.

O'Hea, E. K. \& Leveille, G. A. (1969b). F. Nutr, 99, 338.

Pearce, J. (1968). Biochem. F. ro9, 702.

Pearce, J. (1970). Int. F. Biochem. x, 306.

Pearce, J. (1971a). Biochem. F. 123, 717.

Pearce, J. (1971b). Comp. Biochem. Physiol. 40B, 2 I 5.

Pearce, J. (I971c). Int. F. Biochem. 2, 27r.

Rinaudo, M. T. (1961). Experientia 17, 30 .

Rinaudo, M. T. (1962). Enzymologia 24, 230.

Rinaudo, M. T. \& Galletti, L. (1966). Ital. F. Biochem. r5, 395.

Szepesi, B. \& Freedland, R. A. (1968). 7. Nutr. 95, 591.

Taylor, C. B., Bailey, E. \& Bartley, W. (1967). Biochem. F. ro5, 717.

Viñuela, E., Salas, M. \& Sols, A. (1963). F. biol. Chem. 238, PCi175.

Wallace, J. C. \& Newsholme, E. A. (1967). Biochem. F. ro4, 378.

Yarnell, G. R., Nelson, P. A. \& Wagle, S. R. (1966). Archs Biochem. Biophys. rr4, 539.

Yeh, Y. Y., Leveille, G. A. \& Wiley, J. H. (1970). F. Nutr, 100, 917.

Yeung, D., Stanley, R. S. \& Oliver, I. T. (1967). Biochem. F. 105, 1219.

\title{
Differences in the metabolism of dietary carbohydrates studied in the rat
}

\author{
By D. J. NaIsmith, Department of Nutrition, Queen Elizabeth College, \\ London $\mathrm{W} 8 \mathrm{H}$
}

In the British diet, approximately one-half of the total calories are derived from carbohydrates, of which starch and sucrose together make up more than $90 \%$ $3 \circ(3) 5$ 